\title{
GRAZING EFFECTS OF THE NEW ZEALAND MUD SNAIL ACROSS A PRODUCTIVITY GRADIENT IN THE GREATER YELLOWSTONE ECOSYSTEM
}

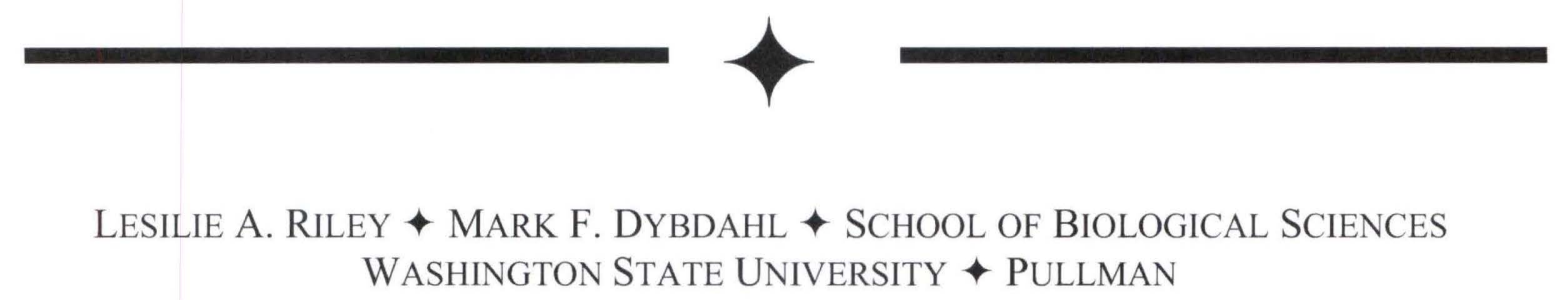

\author{
Robert O. Hall, JR. Department of ZOOlOGy And PhySiology \\ UNIVERSITY OF WYOMING $\downarrow$ LARAMIE
}

\begin{abstract}
$\downarrow \quad$ ABSTRACT
Accurately predicting the effects of introduced species on native communities and ecosystems is a challenge. Utilizing methods of food web ecology, we measured grazing effects of the invasive freshwater New Zealand mud snail, Potamopyrgus antipodarum, in streams within the Greater Yellowstone Ecosystem. Previous results indicate that $P$. antipodarum can significantly reduce algal standing stocks in less than one week, but it is not yet known if grazing effects vary across streams differing in benthic algae production. In this study, we measured the strength of $P$. antipodarum grazing on algal resources across six streams varying widely in ambient primary production. In field enclosure experiments within each stream, we estimated direct grazing effects of snails on algae by measuring chlorophyll $a$, gross primary production and chlorophyll $a$-specific primary production. In most streams, $P$. antipodarum decreased overall algal standing stocks, as measured by chlorophyll $a$, even though gross primary production was not affected. As a result, chlorophyll- $a$ specific primary production increased in productive streams. Finally, standardized comparisons of $P$. antipodarum-algae interactions indicated that grazing effects were largest in the most productive streams. The overall impact of $P$. antipodarum on native stream communities will be greatest in the most productive
\end{abstract}

streams if these assemblages are also capable of supporting dense $P$. antipodarum populations.

\section{$\downarrow$ INTRODUCTION}

Invasive species have changed biodiversity (Wilcove et al. 1998, Mooney and Cleland 2001) and altered ecosystems in profound ways (Vitousek 1990). Population-level effects can be manifested through a multitude of community interactions, including competition (e.g. Petren and Case 1996, Juliano 1998, Byers 2000), predation (e.g.Grosholz et al. 2000), facilitation (e.g. Bruno and Kennedy 2000) and herbivory (e.g. Russell and Louda 2005). Invasive species can also affect ecosystem properties by altering nutrient fluxes or disrupting energy flow (e.g. Hall et al. 2003, Vitousek and Walker 1989). Yet despite the importance of introduced species in affecting native communities and ecosystems, the effects of many successful exotic species are variable or still unknown (Bruno et al. 2005, Strayer 1999) and little attempt has been made to standardize measures of effect with ecological theory (Shea and Chesson 2002).

A central goal of ecology is to determine factors that contribute to variation in species interactions across space. An important conservation implication of this goal is the increased ability to predict impact of invasive species in a variety of 
environments. To facilitate comparisons of introduced species effects across sites, Parker et al. (1999) proposed that overall impact could be related to the combination of three components: range, abundance and per unit effect (e.g. the effect of each individual or unit of biomass). In many instances, range and abundance can be estimated easily, while per unit effects are more difficult to measure. It is possible, though, to experimentally quantify the magnitude of per unit effects of one species on another in a community by calculating interaction strengths (e.g. Paine 1992). Measuring interaction strengths provides an appropriate framework to create standardized comparisons of introduced species effects. Estimates of population-level impacts can be calculated by multiplying interaction strengths by population biomass (Wootton 1997, Parker et al. 1999), assuming that per unit effects scale linearly with biomass (Pfister 1995, Wootton 1997, but see Ruesink 1998). Large effects occur when introduced species interact strongly in the invaded community and especially if they also are abundant.

We were interested in making standardized comparisons of grazing effects of the New Zealand mudsnail (Potamopyrgus antipodarum, Class Prosobranchia, Family Hydrobiidae) on benthic algae across streams varying in primary production levels. $P$. antipodarum, a worldwide invader, was first recorded in streams in the western U.S. in 1987, and now has a widespread, but patchy, distribution, including several areas of conservation significance (e.g. Yellowstone, Grand Teton and Grand Canyon National Parks). $P$. antipodarum grazes on periphytic algae in benthic stream communities and can significantly reduce algal standing stock in less than one week (Riley, Dybdahl and Hall, in review). Within the Greater Yellowstone Ecosystem (GYE), densities of $P$. antipodarum can exceed 500,000 individuals $/ \mathrm{m}^{2}$. Grazing by dense populations of introduced $P$. antipodarum are likely to affect entire stream communities given that benthic algae is energetically important to stream food webs (Lamberti 1996) and can constitute a significant portion of the total energy budget in small, sunny streams (Minshall 1995).

Effects of grazers in streams are not always easy to predict. While it is well-known that herbivorous grazers, especially snails, can significantly reduce periphytic algal standing stocks (e.g. Lamberti et al.1987, Steinman 1996, reviewed in Feminella and Hawkins 1995), the direction or magnitude of these impacts are not consistent across streams (Lamberti and Feminella 1996) and can differ according to the response variables that are measured (Feminella and Hawkins 1995). In general, heavy grazing reduces algal standing stocks (e.g. Hart 1985, Sumner and McIntire 1982, Lamberti 1989), but can increase rates of areal primary production or biomass-specific primary production (Lamberti and Resh 1983). Measuring only one response variable can lead to different conclusions regarding the impact of an invasive grazer on stream communities and ecosystem functions. Consistently, though, the magnitude of grazer effects are more pronounced in streams with higher periphyton biomass and/or primary production (Feminella and Hawkins 1995). If grazing varies predictably across productivity gradients, we can estimate the variation in impact $P$. antipodarum populations have on streams with different levels of benthic algal productivity.

Our study investigated grazing effects of $P$. antipodarum across six streams varying in periphyton abundance and primary production within the GYE. In the summer of 2005, we experimentally assessed the direct impact of $P$. antipodarum snails on standing stocks and production rates of periphytic algae. We then calculated grazing interaction strengths to standardize effect sizes to allow for comparisons across streams. Finally, we analyzed the relationship between primary production and grazing interaction strengths to understand if grazing effects vary predictably with stream production. We found negative grazing effects on algal standing stocks in most streams, with the largest effects in the most productive streams.

\section{$\downarrow$ METHODS}

We experimentally measured grazing effects of $P$. antipodarum in caged experiments in six streams (Polecat, Spirea, Iron Springs, Little Firehole, Fairy and Sentinel) within the Greater Yellowstone Ecosystem. Controlled field experiments are best for determining effects of herbivory and other factors on periphyton (Lamberti and Feminella 1996). Within each stream, we set up ten cages, each containing three - four rocks from the surrounding stream. All other macroinvertebrates were removed from rocks. Five cages received $P$. antipodarum as grazers ( $15 \mathrm{~g} \mathrm{AFDM} / \mathrm{m}^{2}$, equivalent to approximately 600 adult snails) while the other five cages did not receive grazers and served as controls. The biomass of snails used in this experiment fall within the ambient range of $P$. antipodarum in some of these streams (Hall et al. 2003, Kerans et al. 2006). We purposely used the same snail biomass in all experiments for a few 
reasons. First, we wanted to compare grazing effects across streams that vary in production regimes and needed snail biomass to stay constant. Second, as herbivore biomass is increased, periphyton biomass often decreases (Allan 1995). On the other hand, under heavy grazing pressure, productivity per unit of algal biomass can increase (Lamberti and Resh 1983). Testing benthic algal responses, under heavy, but realistic, grazing pressure, should maximize potential differences between production and standing stock responses (Allan 1995, Lamberti and Moore 1984).

At the start of each experiment, we collected benthic algae from nine rocks in the stream and measured ambient chlorophyll $a$ (as an estimate of algal biomass) using standard methods for spectrophotometric analysis (APHA 1995). Each replicate combined algae from three rocks, creating three replicates for ambient initial algal biomass. This allowed us to test for cage effects in all experiments.

At the conclusion of each experiment (average: 5.3 days), chlorophyll $a$ and gross primary production (GPP) were measured from each cage following standard procedures used in other grazing studies in the GYE (APHA 1995, Steinman and Lamberti 1996 and R. O. Hall, Jr. personal communication). We first measured GPP by incubating rocks from each cage in clear and dark PVC plastic tubes, with water continuously pumped in a closed circuit to mimic stream conditions. Oxygen concentrations were recorded with a dissolved oxygen meter (YSI; Yellow Springs, Ohio) at the start of the incubation and one hour later. The decrease in oxygen in the dark chamber represents community respiration (CR), while the change in oxygen in the clear chamber represents net primary production (NPP). NPP $+|\mathrm{CR}|=$ Gross Primary Production, which is the rate of photosynthesis. Next, we scraped periphyton from the rocks to create slurries of algae that we analyzed for chlorophyll $a$ content using standard methods for spectrophotometric analysis (APHA 1995). All chlorophyll a measurements were pheophytin corrected. Finally, rock area was estimated from each cage by tracing the exposed rock surface onto paper. We measured all response variables over two days for each stream because GPP measurements could not be finished in one day given the number of replicates. We calculated three estimates of algal biomass and/or productivity: 1) chlorophyll $a$ $\left(\mathrm{mg} / \mathrm{m}^{2}\right)$ as an estimate of algal standing stock, 2) GPP $\left.\left(\left(\mathrm{mg} \mathrm{O}_{2} / \mathrm{m}^{2}\right) / \mathrm{h}\right)\right)$ as an estimate of production rate per rock area and 3) chlorophyll $a$ - specific GPP
( $\mathrm{mg} \mathrm{O}_{2} / \mathrm{mg}$ chlorophyll $a$ ) as a measure of production per amount of algal standing stock.

We analyzed each response variable separately. First, we combined all streams and used a two-way ANCOVA to test for stream effects, grazing effects and an interaction between stream and grazing, with day of measurement as a covariate. A significant interaction term indicates that the response of benthic algae to grazing is different among streams (i.e. algae decreases in response to grazing in stream A, but increases in stream B). Second, we analyzed each stream individually, using a one-way ANCOVA to test for grazing effects on each of the response variables.

We then standardized grazing estimates in order to make comparisons across streams. Algal reduction by each species was measured as the difference between algal biomass (as estimated by chlorophyll $a$ ) when snails were present compared to the control treatment. We calculated interaction strengths from the following equation, adapted from Wootton (1997):

$$
\frac{\ln \left(\frac{N_{t}, s>0}{N_{t}, s=0}\right)}{S t}=-c
$$

where $N_{t}, s>0$ is the concentration of chlorophyll $a$ ( $\mu \mathrm{g}$ chlorophyll a $/ \mathrm{cm}^{2}$ ) with snails present, $N_{t}, s=0$ is chlorophyll $a\left(\mu \mathrm{g}\right.$ chlorophyll $\left.\mathrm{a} / \mathrm{cm}^{2}\right)$ with snails absent, $S$ is snail biomass (g AFDM) for $N_{t}, s>0, t$ is time (days) and $-c$ is per biomass interaction strength $\left(\left(\mathrm{g} \mathrm{AFDM} / \mathrm{m}^{2}\right)^{-1} \mathrm{~d}^{-1}\right)$. More negative values indicate that algal biomass is lowered to a greater extent per unit of snail biomass per unit of time. This index does not assume equilibrium conditions and works well for short-term experiments (Laska and Wootton 1998; Berlow et al.1999; Berlow et al. 2004). We used a one-way ANOVA to test if interaction strengths differed across streams. We then performed a linear regression to determine if interaction strengths were stronger (i.e. more negative) in streams with higher productivity. The predictor variable was the average GPP from control cages in each stream. Control cages did not experience grazing for the duration of the experiments. All statistics were performed on Systat 10 (SPSS Inc., 2000).

\section{$\downarrow \quad$ RESUlTS}

Initial chlorophyll $a$ measured on rocks in each stream was not different from either control or 
grazing cages for that same stream $(\mathrm{p}=0.515, \mathrm{p}=$ 0.197 respectively). Therefore, cages were representative of ambient stream periphyton conditions. Within experimental cages, streams differed significantly in gross primary production $(\mathrm{p}$ $=0.000$; Table 1). Streams also differed with respect to chlorophyll $a$ and chlorophyll $a$-specific GPP although these results were only marginally significant $(\mathrm{p}=0.087$ and $\mathrm{p}=0.071$, respectively; Table 1, Figure 1

\begin{tabular}{|l|l|l|l|l|}
\hline Response & Stream & Grazing & $\begin{array}{l}\text { Stream x } \\
\text { Grazing }\end{array}$ & $\begin{array}{l}\text { Day } \\
\text { (covariate) }\end{array}$ \\
\hline GPP & $\mathbf{0 . 0 0 0 * *}^{* *}$ & 0.114 & 0.920 & 0.310 \\
\hline Chl- $a$ & $0.087^{*}$ & $\mathbf{0 . 0 0 0 * *}$ & 0.149 & 0.567 \\
\hline $\begin{array}{l}\text { Chl- } a \\
\text { specific GPP }\end{array}$ & $0.071^{*}$ & 0.132 & 0.365 & 0.271 \\
\hline
\end{tabular}

Table 1. Summary table of ANCOVA results for snail grazing across all streams.

Notes: Each response variable was analyzed in a separate two-way ANCOVA and is listed in the left-hand column. Factors included in each ANCOVA were: stream, grazing and day of measurement as the covariate. P-values for the corresponding response variables are listed in the cells in the table.

* Significant $\mathrm{p}$-values at $\mathrm{p}<0.1$.

** Significant $\mathrm{p}$-values at $\mathrm{p}<0.05$.

Overall, grazing trends were similar across streams. Across all streams, grazing did not affect GPP or chlorophyll $a$-specific GPP ( $\mathrm{p}=0.114$ and 0.132 respectively; Table 1$)$. On the other hand, grazing significantly lowered chlorophyll $a$ across all streams $(\mathrm{p}=0.000$; Table 1). For all three response variables, no significant interaction existed between stream and grazing level (Table 1). This indicates that grazing effects were relatively consistent across all six experiments.

Grazing did not significantly affect GPP across all streams, but separate analyses for each stream revealed a significant effect of grazing on GPP in Iron Springs ( $p=0.047$ for grazing; $p=0.003$ for day as the covariate; Table 2; Fig. 2). This result is likely due to significantly lower GPP measurements on day 1 compared to day 2 , rather than a true effect of grazing. Primary production in all other streams was not affected by grazing (Table 2; Fig. 2).

While grazing did not affect GPP, grazing significantly lowered chlorophyll $a$ across all streams (Table 1). Snails were effective at reducing the standing stock of periphyton even though overall production (i.e. GPP) was not affected (Table 2; Figs. 1 and 2). In separate analyses, grazing significantly lowered chlorophyll $a$ in Polecat Creek and Spirea $(p=0.008$ and $p=0.048$, respectively; Table 2, Fig. 2). Grazing effects were also marginally significant in Little Firehole ( $p=0.096$, Table 2, Fig. 2).

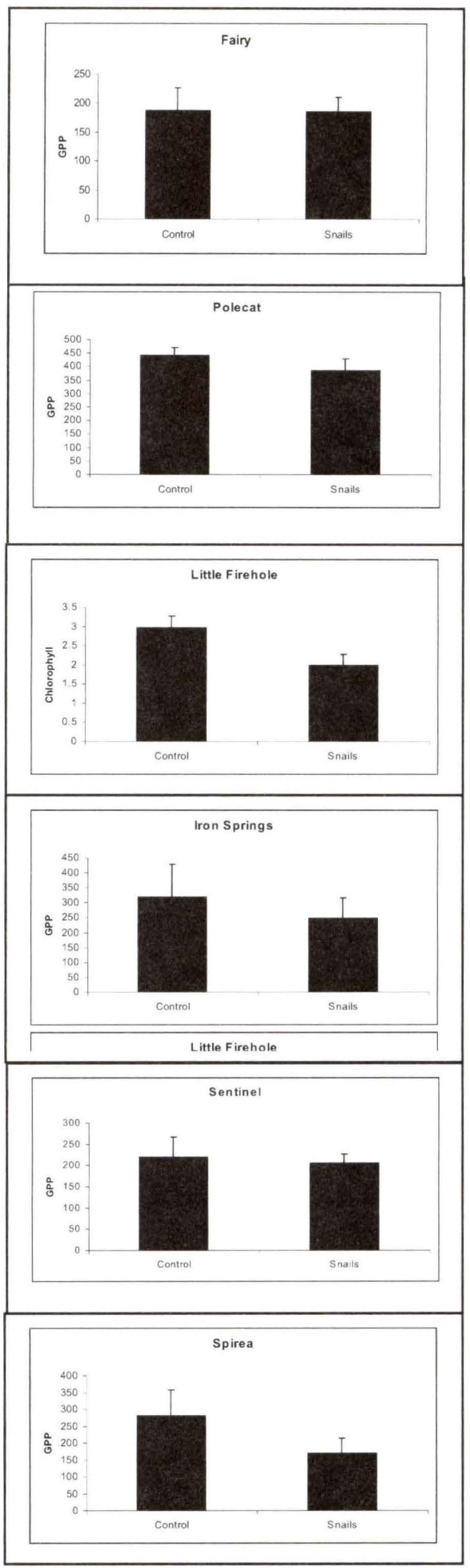

Figure 1. Snail grazing effects on primary production (GPP) in each stream. GPP is measured as $\mathrm{mg} \mathrm{O}_{2} /\left(\mathrm{m}^{2} * \mathrm{~h}\right)$. Grazing only significantly lowered GPP in Iron Springs due to a significant effect of the covariate (day). Note that the y-axis varies among streams. 


\begin{tabular}{|l|l|l|l|}
\hline Stream & GPP & Chl- $a$ & $\begin{array}{l}\text { Chl- } a \\
\text { specific GPP }\end{array}$ \\
\hline Fairy & $0.771(0.244)$ & $0.904(0.533)$ & $0.803(0.895)$ \\
\hline $\begin{array}{l}\text { Iron } \\
\text { Spring }\end{array}$ & $\mathbf{0 . 0 4 7 * * ( 0 . 0 0 3 )} \S$ & $0.404(0.218)$ & $0.381(0.108)$ \\
\hline $\begin{array}{l}\text { Little } \\
\text { Firehole }\end{array}$ & $0.959(0.237)$ & $0.096^{*}(0.206)$ & $0.363(0.818)$ \\
\hline Polecat & $0.314(0.375)$ & $\mathbf{0 . 0 0 8}^{* *}(0.129)$ & $\begin{array}{l}\mathbf{0 . 0 2 6} \\
(0.981)\end{array}$ \\
\hline Spirea & $0.304(0.304)$ & $\mathbf{0 . 0 4 8 * *}(0.938)$ & $0.175(0.848)$ \\
\hline Sentinel & $0.678(0.678)$ & $0.359(0.456)$ & $0.598(0.246)$ \\
\hline
\end{tabular}

Table 2. Summary table of ANCOVA results for snail grazing within each stream.

Notes: Each response variable was analyzed in a separate one-way ANCOVA for each stream. Streams are listed in the left-hand column and $\mathrm{p}$-values for the corresponding response variables are listed in the cells in the table. P-values for day as the covariate are listed in parentheses.

** Significant $\mathrm{p}$-values at $\mathrm{p}<0.05$.

Significant $\mathrm{p}$-values at $\mathrm{p}<0.1$.

$\S$ Significant effect of day as the covariate at $\mathrm{p}<0.05$.

On the other hand, grazing caused slight increases in chlorophyll $a$-specific GPP across all streams, although this result is only significant for Polecat Creek ( $\mathrm{p}=0.026$; Table 2, Fig. 3). Chlorophyll $a$-specific GPP is likely to increase in some streams because snails can reduce the standing stock of periphyton (as estimated by chlorophyll $a$ ), while not affecting the overall rate of photosynthesis (as measured by GPP). This indicates that a smaller standing stock of algae can be responsible for the same amount of primary production.

To facilitate comparisons across streams and productivity regimes, interaction strengths were used to standardize effects of snails on algae and remove any bias that initial differences in algal standing stock might cause (Feminella and Hawkins 1995). Interaction strengths between snails and chlorophyll $a$ differed across streams, with a 10-fold increase from the smallest to the largest interaction strengths $(\mathrm{p}=0.021$; Fig. 4$)$. In addition, GPP in control cages differed across streams, with more than a four-fold difference from the lowest to the highest productivity streams ( $\mathrm{p}=0.000$; Fig. 4). A regression between control GPP and interaction strengths revealed that interaction strengths were strongest (i.e. most negative $)$ in the most productive streams $\left(\mathrm{R}^{2}=0.156\right.$, $\mathrm{p}=0.045$; Fig. 4). Snails were most effective at reducing algal standing stocks in highly productive streams

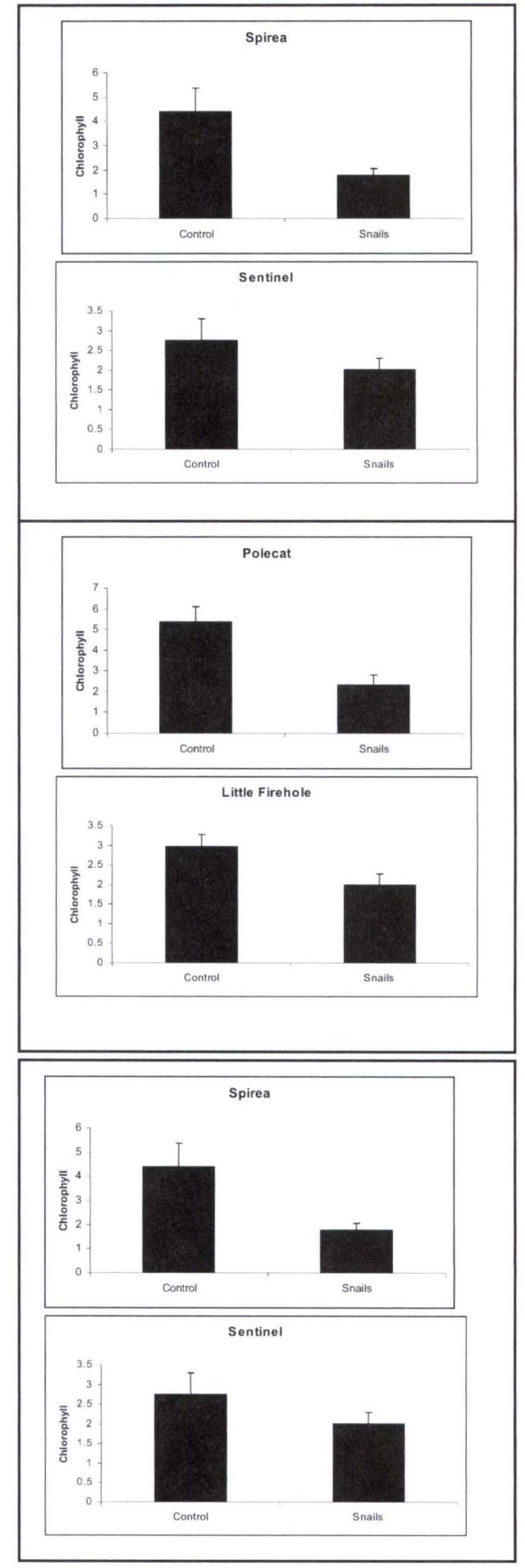

Figure 2. Snail grazing effects on chlorophyll $a$ in each stream. Chlorophyll $a$ is measured as $\mathrm{mg} / \mathrm{m}^{2}$. Grazing significantly lowered chlorophyll $a$ in Polecat Creek and Spirea. At a significance level of $\mathrm{p}=0.1$, grazing also significantly lowered chlorophyll $a$ in Little Firehole. Note that the $y$-axis varies among streams. 


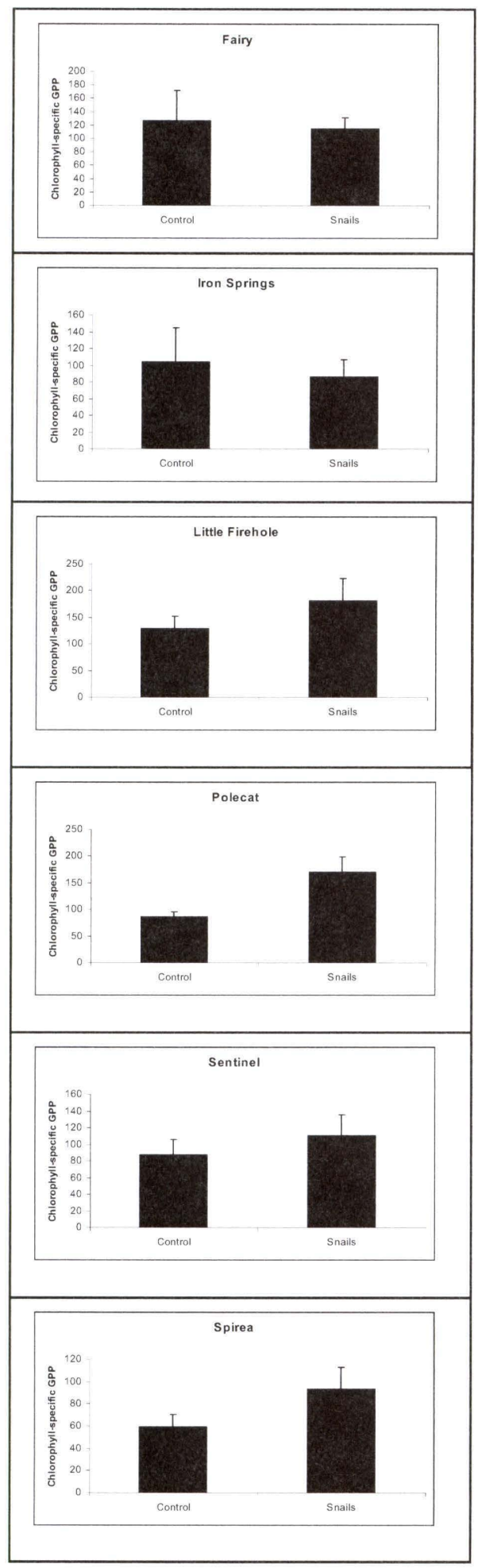

Figure 3. Snail grazing effects on chlorophyll $a$-specific GPP in each stream. Chlorophyll-specific GPP is measured as $\mathrm{mg} \mathrm{O}_{2} / \mathrm{mg}$ chlorophyll $a$. Grazing by snails significantly increased chlorophyll-specific GPP in Polecat Creek. Note that the y-axis varies among streams.
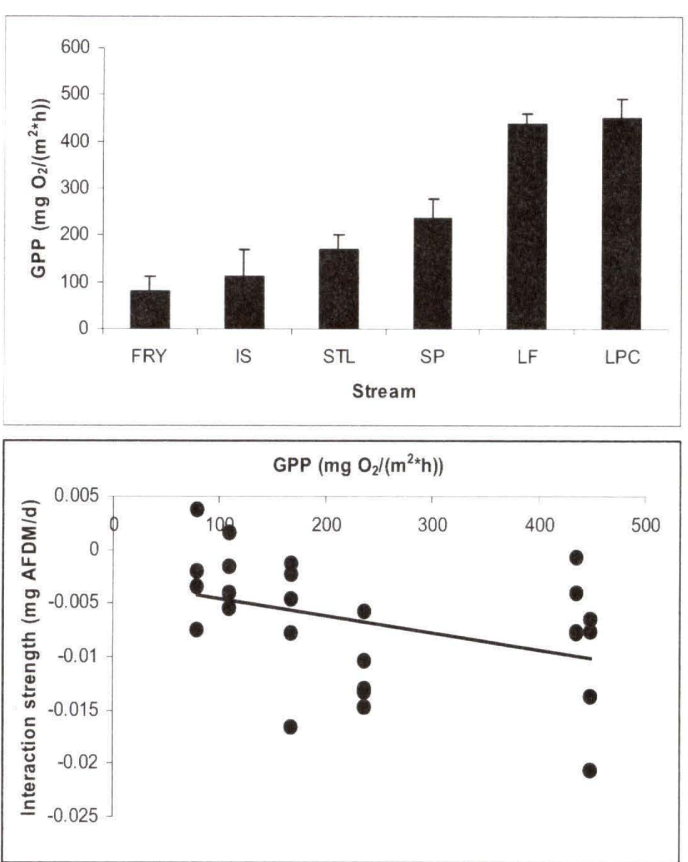

Figure 4. The relationship between GPP and interaction strengths across streams. The top panel represents GPP in control treatments for each stream. Abbreviations are as follows: FRY = Fairy, IS $=$ Iron Springs, $\mathrm{STL}=$ Sentinel, $\mathrm{SP}=$ Spirea, $\mathrm{LF}=$ Little Firehole and $\mathrm{LPC}=$ Polecat Creek. The bottom panel represents the interaction strength between snails and algae, as measured by chlorophyll $a$. See text for explanation of interaction strength calculations. Snails have larger effects in more productive streams $\left(R^{2}=0.156, p=\right.$ $0.045)$.

\section{$\downarrow \quad$ DISCUSSION}

We studied grazing effects of an introduced species, $P$. antipodarum, across a productivity gradient that included six streams in the GYE. We show that intense grazing by $P$. antipodarum did not affect GPP and even had slight positive effects on chlorophyll $a$-specific GPP. On the other hand, $P$. antipodarum reduced standing stocks of algal periphyton in most streams. Grazing effects on periphyton standing stocks were strongest in the most productive streams even though snail biomass remained constant across all experiments. This pattern indicates that $P$. antipodarum has large impacts on basal resources in highly productive streams in the GYE. P. antipodarum grazing impacts might translate into increased growth and/or reproduction, leading to high snail densities in the most productive streams.

Based on the proven effectiveness of snails as grazers in streams (Allan 1995, Lamberti et al. 1987, Steinman 1996), we expected snails to reduce algal resources. We showed that $P$. antipodarum reduced algal standing stocks in most streams. However, P. antipodarum did not affect areal 
primary production, leading to increased primary production per unit of chlorophyll $a$ in the most productive streams. This resulted from a reduced algal standing stock creating the same amount of primary production. This pattern is not surprising given that other studies have also reported similar grazing effects (Lamberti and Resh 1983, indirect evidence: Hill and Knight 1987). Potential mechanisms for increased production with a reduced algal standing stock might include (1) the removal of dominant overstory algae resulting in shade reduction for understory algae, (2) the removal of senescent algae with lower photosynthetic rates creating space for younger, more productive algae to flourish or (3) any combination of (1) and (2) along with increased rates of nutrient regeneration by grazer excretion (Lamberti et al. 1987). In all three scenarios, the grazing effect of the invader would reduce algal standing stocks but increase photosynthetic rates per unit of chlorophyll $a$.

While effects of $P$. antipodarum grazing were similar across all streams, the magnitude of grazing effects increased in the most productive streams. This result might seem counterintuitive at first, but is consistent with a recent meta-analysis examining grazing effects across 89 experimental studies (Feminella and Hawkins 1995). Two mechanisms for large grazing effects in productive streams were proposed by the authors. First, dominant grazer identity varied among streams. Grazers effective at reducing large standing crops are present in highly productive assemblages, but absent in low production streams. Grazers chosen for experimental studies would be more effective in streams with high production. This mechanism, however, cannot account for our results given that grazer identity remained constant across all streams. Second, densities of grazers might be higher in productive areas, resulting in high grazer densities used during experimental trials. Again, this mechanism does not explain the aforementioned results because snail biomass also remained constant across all experiments. A more plausible explanation for this study is that low initial standing stocks can only experience a small reduction. P. antipodarum is capable of larger reductions in more productive streams. If so, we expect that low production streams do not have enough algae to support high growth and/or reproductive rates of $P$. antipodarum. This would lead to low production streams having lower densities of $P$. antipodarum. We are currently examining this final mechanism.

Our approach using standardized measures of grazing effects has demonstrated the potential for the introduced $P$. antipodarum to impact resource availability across streams in the GYE. Intense grazing pressure by $P$. antipodarum reduced algal standing stocks and increased chlorophyll $a$-specific primary production in highly productive streams. The overall impact of $P$. antipodarum on algal resources will be magnified in these streams if highly productive assemblages are also capable of supporting dense populations of $P$. antipodarum. These results indicate that $P$. antipodarum has the potential to dramatically alter algal assemblages if intense grazing persists in productive streams.

\section{$\downarrow$ Literature Cited}

Allan, J.D. 1995. Stream ecology: structure and function of running waters. Kluwer Academic Publishers, Dordrecht, The Netherlands.

APHA. 1995. Standard methods for the examination of water and wastewater. Port City Press, Baltimore, Maryland.

Berlow, E.L., S.A. Navarrete, C.J.Briggs, M.E. Power and B.A. Menge. 1999. Quantifying variation in the strengths of species interactions. Ecology 80: 2206-2224.

Berlow, E.L., A.M. Neutel, J.E. Cohen, P.C de Ruiter, B. Ebenman, M. Emmerson, J.W. Fox, V.A.A. Jansen, J.L. Jones, G.D. Kokkoris, D.O. Logofet, A.J. McKane, J.M. Motoya and O. Petchey. 2004. Interaction strengths in food webs: issues and opportunities. Journal of Animal Ecology 73: $585-598$.

Bruno, J.F. and C.W. Kennedy. 2000. Patch-size dependent habitat modification and facilitation on New England cobble beaches by Spartina alterniflora. Oecologia 122: 98 -108 .

Bruno, J.F., J.D.Fridley, K.D. Bromberg and M.D. Bertness. 2005. Insights into biotic interactions from studies of species invasions. In: Sax D.F., Stachowicz J.J. and Gaines S.D. (eds) Species invasions: insights into ecology, evolution and biogeography, pp 13-40. Sinauer Associates Inc, Sunderland, MA. 
Byers, J.E. 2000. Competition between two estuarine snails: implications for invasions of exotic species. Ecology 81: 1225-1239.

Feminella, J.W. and C.P. Hawkins. 1995. Interactions between stream herbivores and periphyton: a quantitative analysis of past experiments. Journal of the North American Benthological Society 14: $465-509$.

Grosholz, E.D., G.M. Ruiz, C.A. Dean, K.A. Shirley, J.L. Maron and P.G. Connors. 2000. The impacts of a nonindigenous marine predator in a California bay. Ecology 81:1206 - 1224

Hall, R.O., J.L. Tank and M.F. Dybdahl. 2003. Exotic snails dominate nitrogen and carbon cycling in a highly productive stream. Frontiers in Ecology and the Environment 1: 407-411.

Hart, D.D.1985. Grazing insects mediate algal interactions in a stream benthic community. Oikos 44: 40-46.

Hill, W.R. and A.W. Knight. 1987. Experimental analysis of the grazing interaction between a mayfly and stream algae. Ecology 68: 19551965.

Juliano, S.A. 1998. Species introduction and replacement among mosquitoes: interspecific resource competition or apparent competition? Ecology 79: 255-268.

Kerans, B.L., M.F. Dybdahl, M.M. Gangloff and J.E. Jannot. 2005. Potamopyrgus antipodarum: distribution, density, and effects on native macroinvertebrate assemblages in the Greater Yellowstone Ecosystem. Journal of the North American Benthological Society $24: 123-138$.

Lamberti, G.A. and V.H. Resh. 1983. Stream periphyton and insect herbivores: an experimental study of grazing by a caddisfly population. Ecology 64: 1124-1135.

Lamberti, G.A. and Moore J.W. 1984. Aquatic insects as primary consumers, In: The Ecology of Aquatic Insects, (eds. VH Resh and DM Rosenberg), Praeger Scientific, New York, pp. 164-195.
Lamberti, G.A., L.R. Ashkenas, S.V. Gregory and A.D. Steinman. 1987. Effects of three herbivores on periphyton communities in laboratory streams. Journal of the North American Benthological Society 6:92 - 104.

Lamberti, G.A., S.V. Gregory, L.R. Ashkenas, A.D. Steinman and C.D. McIntire. 1989. Productive capacity of periphyton as a determinant of plant-herbivore interactions in streams. Ecology 70: 1840-1856.

Lamberti, G.A. and J.W. Feminella. 1996. Plantherbivore interactions. Pages $409-430$ In: FR Hai=uer and G.A. Lamberti (eds.) Methods in Stream Ecology. Academic Press: San Diego CA.

Laska, M.S. and J.T. Wootton. 1998. Theoretical concepts and empirical approaches to measuring interaction strengths. Ecology 79: 461-476.

Minshall, G.W., C.T. Robinson, T.V. Royer and S.R. Rushforth. 1995. Benthic community structure in two adjacent streams in Yellowstone National Park five years after the 1988 wildfires. The Great Basin Naturalist 55 (3): 193-200.

Mooney, H.A. and E.E. Cleland. 2001. The evolutionary impact of invasive species. Proceedings of the National Academy of Sciences of the United States of America 98: 5446-5451.

Paine, R.T. 1992. Food-web analysis through field measurement of per capita interaction strength. Nature 355: 73-75.

Parker, I.M., D. Simberloff, W.M. Lonsdale, K. Goodell, M. Wonham, P.M. Kareiva, M.H. Williamson, B. Von Holle, P.B. Moyle, J.E. Byers and L. Goldwasser. 1999. Impact: toward a framework for understanding the ecological effects of invaders. Biological Invasions 1: 3-19.

Petren, K. and T.J. Case.1996. An experimental demonstration of exploitation competition in an ongoing invasion. Ecology 77: 118-132. 
Pfister, C.A. 1995. Estimating competition coefficients from census data: a test with field manipulations of tidepool fishes. The American Naturalist 146:271 - 291.

Riley, L.A., Dybdahl M.F. and Hall, R.O. Jr. In review. Grazing and competition interaction strengths match patterns of introduced species dominance.

Ruesink, J.L.1998. Variation in per capita interaction strength: Thresholds due to nonlinear dynamics and nonequilibrium conditions. Proceedings of the National Academy of Sciences of the United States of America 95: 6843-6847.

Russell, F.L. and S.M. Louda. 2005. Indirect interaction between two native thistles mediated by an invasive exotic floral herbivore. Oecologia 146 (3): 373-384.

Shea, K. and P. Chesson.2002. Community ecology theory as a framework for biological invasions. Trends in Ecology and Evolution 17 (4): 171-176.

Steinman, A.D. 1996. Effects of grazers on freshwater benthic algae. In: Stevenson, RJ, Bothwell, ML and Lowe RL (eds) Algal Ecology: Freshwater Benthic Ecosystems. Academic Press, San Diego, CA.
Strayer, D.L. 1999. Effects of alien species on freshwater mollusks in North America. Journal of the North American Benthological Society 18: 74-98.

Sumner, W.T. and C.D McIntire. 1982. Grazerperiphyton interactions in laboratory streams. Arch. Hydrobiol. 93:135-157.

Systat 10. SPSS, Inc. 2000.

Vitousek, P.M. and L.R. Walker. 1989. Biological invasion by Myrica faya in Hawaii: Plant demography, nitrogen fixation and ecosystem effects. Ecological Monographs 59: $247-265$

Vitousek, P.M. 1990. Biological invasions and ecosystem processes: towards an integration of population biology and ecosystem studies. Oikos 57: 7 - 13 .

Wilcove, D.S., D. Rothstein, J. Dubow, A. Phillips, and E. Losos. 1998. Quantifying threats to imperiled species in the United States. Bioscience 48: 607-615.

Wooton, J.T. 1997. Estimate and tests of per capita interaction strength: diet, abundance, and impact of intertidally foraging birds. Ecological Monographs 67: 45-64. 